\title{
An evaluation of the use of sideral precursors and biologics in the cultivation of long-legged flax
}

\author{
Galina Efremova* \\ Ivanovo SAA, ul. Sovetskaya, d. 45, g. Ivanovo, obl. Ivanovskaya, 153012, Russian Federation.
}

\begin{abstract}
The paper presents data on the study of the effectiveness of new biological drugs-the biofungicides Trichozan and Vitariz and biological insecticide against the background of the action and aftereffect of the sideral precursors of long-legged flax. The research was conducted in the Scientific Research Center of the Ivanovo State Agricultural Academy in 2018-2020. The positive effect of the action and aftereffect of the sideral precursors on the productivity of plants and the yield of flax was established. The greatest increases in the yield of straw and seeds were obtained in 2019-2020 when flax was placed after the sideral precursors and the complex use of the biological products Trichozan, Vitariz, and Bioinsecticide. The quality of flax straw improved by $0.5-0,25$ sortonomer with the interaction of the complex of biological products and the action of siderates and by 0.25 sortonomer-with the use of biological products for the treatment of seeds and plants against the background of the aftereffect of siderates. The level of profitability for the years increased by $41.9-11.7 \%$, respectively.
\end{abstract}

\section{Introduction}

The basis of modern technologies for growing crops is the development and implementation of organic farming, the use of preparations of natural origin (Melnikova, 2019). Siderates play an agroecological role in the system of biologization of agriculture, reproduction of soil fertility, and rational use of mineral fertilizers (Efremova, Zotova, 2020; Bashkov, Bortnik, 2012; Esedullaev, Melsaev, 2019). The study of new predecessors of fiber flax, their aftereffects is a very urgent topic of research aimed at achieving the productivity potential of varieties. Biologized technologies are also based on the use of biological products to stimulate plant growth and protect against pathogens. The effectiveness of biological drugs has been confirmed by several scientific studies (Chudinova, 2011; Korepanova, 2014; Yakovleva, Vasiliev, 2020). A review of literature data shows that the biological products used in the experiments contributed to an increase in the yield of straw and seeds by $16-18 \%$, the level of productivity was $7.2 \mathrm{c} /$ ha of seeds and $11.7 \mathrm{t} /$ ha of long fiber, therefore there are reserves for increasing the yield of cultivated based on the use of more effective preparations and technology for growing flax according to new predecessors. The biopreparations Trihozan and Vitariz, Bioinsecticide, green manure precursors of fiber flax used in the experiments have not been studied before.

\section{Formulation of the problem}

The search for new precursors and effective biological preparations in flax cultivation is necessary in order to increase soil fertility, increase the efficiency of the protection system and stimulation of plant growth and development, aimed at obtaining the potential yield of zoned varieties and improving the quality of grown products.

\section{Description of the studied subject of the article}

In field experiments, new preparations were studied based on bacteria and fungi - Vitariz and Trihozan, which have a growth-stimulating and fungicidal effect. Vitaris is obtained based on Pseudomonas fluorescens, Trichozan - the preparation contains a fungus of the genus Trichoderma Trichoderma Lignorum, Bioinsecticide contains a combination of natural avermectins, which are produced by non-pathogenic soil fungi Bacillus thuringiensis, Streptomyces sp., Beauveria bassiana. Trihozan - 31 / ha was applied in autumn, after harvesting the predecessor, and in spring, under presowing cultivation at a dose of $21 / \mathrm{ha}$. Trihozan $-11 / \mathrm{t}$ and Vitariz $-11 / \mathrm{t}$ were used for sequential dressing of seeds before sowing. Vitariz - $11 /$ ha was used for the double treatment of plants during the growing season, Bioinsecticide - $31 /$ ha - for a single treatment in the herringbone phase.

To increase the biological activity of the preparations, Fertility Universal humate was added to the working fluid at a dose of $300 \mathrm{ml} / \mathrm{ha}$. Sowing of green manure was carried out in 2018 in 2 terms: 1 term - in May, 2 term - in July. The seeding rate of mustard seeds is $20 \mathrm{~kg} / \mathrm{ha}$, peas in mixed sowing - $200 \mathrm{~kg} / \mathrm{ha}(2$ million seeds per $1 \mathrm{ha})$, oats $-35 \mathrm{~kg} / \mathrm{ha}(1.2$ million seeds per 1

\footnotetext{
*Corresponding author: efremova37@bk.ru
} 
ha). Seeds of green manure crops before sowing were treated with a $2 \%$ solution of the growth stimulator "Energen Aqua". Mineral fertilizers were applied before presowing cultivation at the rate of N12P40K40. Sowing of flax variety Tomskiy -17 was carried out in 2019 after green manure predecessors with the SSNP-16 selection seeder with row spacing of $10 \mathrm{~cm}$. The seeding rate is 23 million viable seeds per hectare. For sowing, conditioned seeds of the first reproduction were used.

Research Objective: to establish the effect and aftereffect of green manure predecessors and biological products on plant productivity and the yield of fiber flax.

\section{Research methods}

The studies were carried out following the method of conducting field experiments with fiber flax (Dolgov, Kovalev, 1978). The study uses the methods of soil research and determination of the quality of flax straw. Statistical processing of the experimental data was carried out by the method of analysis of variance according to B. A.Dospekhov. The experiment scheme in 2018 included 5 options, 4 replicates, in $2019-6$ options, 4 replicates, in 2020 - 4 options, 4 replicates. The total area of the plot is $40 \mathrm{~m}^{2}$, the location of the plots is consistent.

\section{Rresults and discussion}

Table 1. Elements of the structure of fiber flax yield when using green manure predecessors and biological products, 2019

\begin{tabular}{|c|c|c|c|c|}
\hline Variants & $\begin{array}{c}\text { Plant } \\
\text { density, } \\
\text { pcs / } \mathrm{m}^{2}\end{array}$ & $\begin{array}{c}\text { Number } \\
\text { of bolls } \\
\text { per } \\
\text { plant, } \\
\text { pcs }\end{array}$ & $\begin{array}{c}\text { Straw } \\
\text { weight } \\
\text { from 50 } \\
\text { rth, g }\end{array}$ & $\begin{array}{c}\text { Seed } \\
\text { weight } \\
\text { from 50 } \\
\text { rth, g }\end{array}$ \\
\hline Spring cereals & 1650 & 2.1 & 15.5 & 2.0 \\
\hline Pea-oats & 1792 & 3.2 & 22.4 & 3.0 \\
\hline \begin{tabular}{c} 
Mustard \\
\hline $\begin{array}{c}\text { Pea-oats + Trihozan + } \\
\text { Vitariz }\end{array}$
\end{tabular} & 17948 & 2.4 & 21.9 & 3.1 \\
\hline $\begin{array}{c}\text { Mustard + Trihozan + } \\
\text { Vitariz }\end{array}$ & 1392 & 3.3 & 29.8 & 4.55 \\
\hline $\begin{array}{c}\text { Pea-oats + Trihozan + } \\
\text { Vitariz + } \\
\text { Bioinsecticide }\end{array}$ & 1728 & 3.6 & 30.1 & 6.4 \\
\hline $\begin{array}{c}\text { Mustard + Trihozan + } \\
\text { Vitariz } \\
+ \text { Bioinsecticide }\end{array}$ & 1488 & 4.3 & 31.0 & 6.8 \\
\hline
\end{tabular}

The results of counting the number of bolls per plant, the mass of straw, and the mass of seeds from 50 plants showed the advantage of using white mustard as a green manure precursor and biological products. The density of standing of fiber flax plants before harvesting is higher when plowing peas with oats and using biological products, which is associated with the possibility of more thorough incorporation of green mass in comparison with mustard (Table 1).

Table 2. Influence of green manure and biological products on the yield of fiber flax, 2019

\begin{tabular}{|c|c|c|c|c|c|c|}
\hline \multirow[t]{2}{*}{ Variants } & \multicolumn{2}{|c|}{$\begin{array}{c}\text { Productivity } \\
\text { c / ha }\end{array}$} & \multicolumn{2}{|c|}{$\begin{array}{l}\text { Addition to } \\
\text { control, c / } \\
\text { ha }\end{array}$} & \multicolumn{2}{|c|}{$\begin{array}{c}\text { Increase from } \\
\text { biological } \\
\text { products, c / } \\
\text { ha }\end{array}$} \\
\hline & straw & seed & straw & seed & straw & seed \\
\hline Spring cereals & 54.3 & 5.1 & - & - & - & - \\
\hline Pea-oats & 80.3 & 7.6 & 26.0 & 2.5 & - & - \\
\hline Mustard & 72.2 & 7.1 & 17.9 & 2.0 & - & - \\
\hline $\begin{array}{c}\text { Pea-oats }+ \text { Trihozan }+ \\
\text { Vitariz }\end{array}$ & 85.7 & 7.8 & 31.4 & 2.7 & 5.4 & 0.2 \\
\hline $\begin{array}{c}\text { Mustard }+ \text { Trihozan }+ \\
\text { Vitariz }\end{array}$ & 83.0 & 8.9 & 28.7 & 3.8 & 10.8 & 1.8 \\
\hline $\begin{array}{c}\text { Pea-oats }+ \text { Trihozan }+ \\
\text { Vitariz }+ \\
\text { Bioinsecticide }\end{array}$ & 104.0 & 15.5 & 49.7 & 10.4 & 23.7 & 7.9 \\
\hline $\begin{array}{c}\text { Mustard + Trihozan }+ \\
\text { Vitariz }+ \\
\text { Bioinsecticide }\end{array}$ & 92.3 & 14.1 & 38.0 & 9.0 & 20.1 & 7.0 \\
\hline HCP05 & 15.6 & 2.8 & & & & \\
\hline
\end{tabular}

The yield of fiber flax straw in 2019 increased against the background of the predecessor peas + oats by $47.9 \%$, against the background of mustard - by $33.0 \%$, the yield of seeds increased by $49.0-39.2 \%$, respectively (Table 2).

Biologics were characterized by growth-stimulating effects. The greatest increase in the yield of seeds and straw was obtained with the integrated use of biological products: Trihozan (soil treatment) + Vitariz and Trihozan (sequential seed dressing) + Vitariz (plant treatment) + Bioinsecticide (plant treatment). The increase in straw yield was $49.7 \mathrm{c} / \mathrm{ha}(91.5 \%)$ for the pea-oats background and $38 \mathrm{c} / \mathrm{ha}(70 \%)$ for the mustard background. The seed yield increased by 10.4-9.0 centner/ha, respectively (203.9-176.4\%), significant increases in the yield of flax products were obtained for both predecessors (Table 2).

In 2020, the largest increases in straw and seed yield were also obtained with the integrated use of biological products. The increase in straw yield was $22.6 \mathrm{c} / \mathrm{ha}$ (75.3\%), seeds $-2.7 \mathrm{c} / \mathrm{ha}(69.2 \%)$. The total yield of flax products decreased compared to 2019 due to a decrease in plant density due to an increase in weediness of crops (Table 3). 
Table 3. Influence of green manure aftereffect on the formation of fiber flax yield, 2020

\begin{tabular}{|c|c|c|c|c|c|c|}
\hline \multirow[t]{2}{*}{ Variants } & \multirow{2}{*}{$\begin{array}{l}\text { Density } \\
\text { of } \\
\text { standin } \\
\text { g of } \\
\text { plants, } \\
\text { pcs / m² }\end{array}$} & \multirow{2}{*}{$\begin{array}{l}\text { Straw } \\
\text { weigh } \\
\mathrm{t} \text { from } \\
50 \\
\text { plants, } \\
\mathrm{g}\end{array}$} & \multirow{2}{*}{$\begin{array}{l}\text { Seed } \\
\text { weigh } \\
\mathrm{t} \text { from } \\
50 \\
\text { plants, } \\
\mathrm{g}\end{array}$} & \multirow{2}{*}{$\begin{array}{l}\text { The } \\
\text { numbe } \\
\text { r of } \\
\text { boxes } \\
\text { per } \\
\text { plant, } \\
\text { pcs. }\end{array}$} & \multicolumn{2}{|c|}{$\begin{array}{l}\text { Productivity } \\
\mathrm{e} \text { / / ha }\end{array}$} \\
\hline & & & & & 胥 & $\begin{array}{l}\mathbb{D} \\
\mathbb{W} \\
\text { D. }\end{array}$ \\
\hline $\begin{array}{l}\text { Background - } \\
\text { Pea-oats for } \\
\text { grain }\end{array}$ & 720 & 20.8 & 3.6 & 3.3 & 30.0 & 3.9 \\
\hline $\begin{array}{l}\text { Background } \\
+ \text { Trihozan + } \\
\text { Vitariz (seed } \\
\text { treatment) }\end{array}$ & 792 & 22.3 & 5.1 & 4.1 & 33.3 & 5.2 \\
\hline $\begin{array}{l}\text { Background } \\
+ \text { Trihozan } \\
\text { (seed } \\
\text { treatment) + } \\
\text { Vitariz (seed } \\
\text { and plant } \\
\text { treatment) }\end{array}$ & 784 & 31.8 & 7.7 & 5.4 & 49.9 & 5.3 \\
\hline $\begin{array}{l}\text { Background } \\
+ \text { Trihozan } \\
\text { (seed } \\
\text { treatment) + } \\
\text { Vitaris (seed } \\
\text { and plant } \\
\text { treatment) + } \\
\text { Bioinsecticid } \\
\text { e }\end{array}$ & 792 & 33.2 & 7.9 & 5.9 & 52.6 & 6.6 \\
\hline HCP05 & & & & & 15.9 & 2.08 \\
\hline
\end{tabular}

In 2020, the largest increases in straw and seed yield were also obtained with the integrated use of biological products. The increase in straw yield was $22.6 \mathrm{c} / \mathrm{ha}$ (75.3\%), seeds $-2.7 \mathrm{c} / \mathrm{ha}(69.2 \%)$. The total yield of flax products decreased compared to 2019 due to a decrease in plant density due to an increase in weediness of crops (Table 4).

Green manure precursors and biological products had a positive effect on the quality of fiber flax straw compared to the cultivation technology after the cereal predecessor. The quality of straw improved with the complex use of biological products against the background of mustard by 0.5 sortonomer compared to spring grain crops and by 0.25 sortonomer compared to mustard (Table 5).

The use of biological products for the treatment of seeds and plants against the background of the green manure aftereffect improved the quality of straw in 2020 , by 0.25 sortonomer compared to the background without the use of biological products (Table 6).

Additional costs for the use of green manure and biological products were paid off by additional net income, the level of profitability increased compared to the placement of flax after spring crops by $41.9 \%$ for the background of peas with oats and by $29.8 \%$ for the background of mustard (Table 7).
Table 4. Influence of green manure aftereffect on the formation of fiber flax yield, 2020

\begin{tabular}{|c|c|c|c|c|c|c|}
\hline \multirow[t]{2}{*}{ Variants } & \multirow{2}{*}{$\begin{array}{l}\text { Density } \\
\text { of } \\
\text { standin } \\
\mathrm{g} \text { of } \\
\text { plants, } \\
\mathrm{pcs} / \mathrm{m}^{2}\end{array}$} & \multirow{2}{*}{$\begin{array}{l}\text { Straw } \\
\text { weigh } \\
\text { t from } \\
50 \\
\text { plants, } \\
\text { g }\end{array}$} & \multirow{2}{*}{$\begin{array}{l}\text { Seed } \\
\text { weigh } \\
\mathrm{t} \text { from } \\
50 \\
\text { plants, } \\
\mathrm{g}\end{array}$} & \multirow{2}{*}{$\begin{array}{l}\text { The } \\
\text { numbe } \\
\mathrm{r} \text { of } \\
\text { boxes } \\
\text { per } \\
\text { plant, } \\
\text { pcs. }\end{array}$} & \multicolumn{2}{|c|}{$\begin{array}{l}\text { Productivity } \\
\text {, c/ha }\end{array}$} \\
\hline & & & & & 总 & 总 \\
\hline $\begin{array}{l}\text { Background - } \\
\text { Pea-oats for } \\
\text { grain after } \\
\text { green manure } \\
\text { predecessor }\end{array}$ & 720 & 20,8 & 3,6 & 3,3 & 30,0 & 3,9 \\
\hline $\begin{array}{l}\text { Trihozan }+ \\
\text { Vitariz (seed } \\
\text { treatment) }\end{array}$ & 792 & 22,3 & 5,1 & 4,1 & 33,3 & 5,2 \\
\hline $\begin{array}{l}\text { Trihozan } \\
\text { (seed } \\
\text { treatment) + } \\
\text { Vitariz (seed } \\
\text { and plant } \\
\text { treatment) }\end{array}$ & 784 & 31,8 & 7,7 & 5,4 & 49,9 & 5,3 \\
\hline $\begin{array}{l}\text { Trihozan } \\
\text { (seed } \\
\text { treatment) + } \\
\text { Vitariz (seed } \\
\text { and plant } \\
\text { treatment) + } \\
\text { Bioinsecticid } \\
\text { e (plant } \\
\text { treatment) }\end{array}$ & 792 & 33,2 & 7,9 & 5,9 & 52,6 & 6,6 \\
\hline HCP05 & & & & & 15,9 & $\begin{array}{l}2,0 \\
8\end{array}$ \\
\hline
\end{tabular}

Table 5. Influence of green manure and biological products on the quality of fiber flax straw, 2019

\begin{tabular}{|c|c|c|c|c|c|c|}
\hline Variants & $\begin{array}{c}\text { Handf } \\
\text { ul } \\
\text { length, } \\
\mathrm{cm}\end{array}$ & $\begin{array}{c}\text { Suitab } \\
\text { ility }\end{array}$ & $\begin{array}{c}\text { Bast } \\
\text { conten } \\
\text { t, } \%\end{array}$ & $\begin{array}{c}\text { Bast } \\
\text { fortres } \\
\text { s, kgf }\end{array}$ & $\begin{array}{c}\text { Points } \\
\text { total }\end{array}$ & $\begin{array}{c}\text { Sort } \\
\text { numbe } \\
\mathrm{r}\end{array}$ \\
\hline $\begin{array}{c}\text { Spring } \\
\text { cereals }\end{array}$ & 65.3 & 0.88 & 25.0 & 6.5 & 82.0 & 0.75 \\
\hline Pea-oats & 70.0 & 0.87 & 30.0 & 6.7 & 94.0 & 1.00 \\
\hline Mustard & 70.0 & 0.88 & 27.0 & 7.0 & 95.0 & 1.00 \\
\hline $\begin{array}{c}\text { Pea-oats + } \\
\text { Trihozan + } \\
\text { Vitariz }\end{array}$ & 70.0 & 0.89 & 25.0 & 7.0 & 87.0 & 1.00 \\
\hline $\begin{array}{c}\text { Mustard + } \\
\text { Trihozan + } \\
\text { Vitariz }\end{array}$ & 70.0 & 0.94 & 25.0 & 7.0 & 89.0 & 1.00 \\
\hline $\begin{array}{c}\text { Pea-oats }+ \\
\text { Trihozan + } \\
\text { Vitariz + } \\
\text { Bioinsectici } \\
\text { de }\end{array}$ & 72.0 & 0.91 & 27.0 & 6.7 & 92.0 & 1.00 \\
\hline $\begin{array}{c}\text { Mustard + } \\
\text { Trihozan + } \\
\text { Vitariz + } \\
\text { Bioinsectici } \\
\text { de }\end{array}$ & 73.5 & 0.92 & 33.0 & 9.5 & 105.0 & 1.25 \\
\hline
\end{tabular}


Table 6. Effect of post-emergent sideratum on the quality of long-fibre flax straw, 2020

\begin{tabular}{|c|c|c|c|c|c|c|}
\hline Variants & $\begin{array}{c}\text { Handful } \\
\text { length, cm }\end{array}$ & Suitability & $\begin{array}{c}\text { Bast } \\
\text { content, \% }\end{array}$ & $\begin{array}{c}\text { Bast } \\
\text { fortress, kgf }\end{array}$ & $\begin{array}{c}\text { Points } \\
\text { total }\end{array}$ & $\begin{array}{c}\text { Sort } \\
\text { number }\end{array}$ \\
\hline Background - Pea-oats for grain & 71.0 & 0.85 & 28.0 & 6.8 & 96.0 & 1.00 \\
\hline Background + Trihozan + Vitariz (seed treatment) & 74.5 & 0.90 & 28.0 & 7.5 & 96.0 & 1.00 \\
\hline $\begin{array}{c}\text { Background + Trihozan (seed treatment) + Vitariz } \\
\text { (seed and plant treatment) }\end{array}$ & 86.0 & 0.92 & 31.0 & 7.8 & 107.0 & 1.25 \\
\hline $\begin{array}{c}\text { Background + Trihozan (seed treatment) + Vitaris } \\
\text { (seed and plant treatment) + Bioinsecticide }\end{array}$ & 80.5 & 0.91 & 27.0 & 8.0 & 99.0 & 1.25 \\
\hline
\end{tabular}

Table 7. Economic efficiency of the use of green manure predecessors and biological products in the cultivation of fiber flax, 2019

\begin{tabular}{|c|c|c|c|c|c|c|}
\hline \multirow[t]{2}{*}{ Variants } & \multicolumn{2}{|c|}{$\begin{array}{c}\text { Productivity, c / } \\
\text { ha }\end{array}$} & \multirow[t]{2}{*}{$\begin{array}{l}\text { Harvest cost, } \\
\text { rubles/ha }\end{array}$} & \multirow[t]{2}{*}{$\begin{array}{l}\text { Cost of costs, } \\
\text { rubles/ha }\end{array}$} & \multirow[t]{2}{*}{$\begin{array}{l}\text { conditional net income, } \\
\text { rubles/ha }\end{array}$} & \multirow[t]{2}{*}{ Profitability, $\%$} \\
\hline & seed & straw & & & & \\
\hline Spring cereals & 5.1 & 54.3 & 170716 & 134519 & 37197 & 27.7 \\
\hline Pea-oats + Energen & 7.6 & 80.3 & 252625 & 178199 & 74435 & 41.8 \\
\hline Mustard + Energen & 7.1 & 72.2 & 227908 & 168357 & 59551 & 35.4 \\
\hline Pea-oats + Trihozan + Vitariz & 7.8 & 85.7 & 268720 & 183579 & 85141 & 46.4 \\
\hline Mustard + Trihozan + Vitariz & 8.9 & 83.0 & 264121 & 182091 & 82030 & 45.0 \\
\hline $\begin{array}{l}\text { Pea-oats + Trihozan + Vitariz }+ \\
\text { Bioinsecticide }\end{array}$ & 15.5 & 104.0 & 343730 & 202701 & 141029 & 69.6 \\
\hline $\begin{array}{l}\text { Mustard + Trihozan + Vitariz + } \\
\text { Bioinsecticide }\end{array}$ & 14.1 & 92.3 & 306081 & 194318 & 111763 & 57.5 \\
\hline
\end{tabular}

Table 8. Economic efficiency of the aftereffect of green manure predecessors and biological products in the cultivation of fiber flax, 2020

\begin{tabular}{|c|c|c|c|c|c|c|}
\hline \multirow{2}{*}{ Variants } & \multicolumn{2}{|c|}{$\begin{array}{c}\text { Productivi } \\
\text { ty, c/ha }\end{array}$} & \multirow{2}{*}{$\begin{array}{c}\text { Harves } \\
\text { t cost, } \\
\text { rubles/ } \\
\text { ha }\end{array}$} & \multirow{2}{*}{\begin{tabular}{|c|}
$\begin{array}{c}\text { Cost of } \\
\text { costs, } \\
\text { rubles/ } \\
\text { ha }\end{array}$ \\
\end{tabular}} & \multirow{2}{*}{$\begin{array}{c}\text { conditio } \\
\text { nal net } \\
\text { income, } \\
\text { rubles/ha }\end{array}$} & \multirow{2}{*}{$\begin{array}{c}\text { Profitability } \\
, \%\end{array}$} \\
\hline & seed & straw & & & & \\
\hline $\begin{array}{c}\text { Backgroun } \\
\mathrm{d} \text { - Pea-oats } \\
\text { for grain } \\
\text { after green } \\
\text { manure } \\
\text { predecessor }\end{array}$ & 3.9 & 30.0 & 97429 & 76091 & 20476 & 26.9 \\
\hline $\begin{array}{c}\text { Trihozan }+ \\
\text { Vitariz } \\
\text { (seed } \\
\text { treatment) }\end{array}$ & 5.2 & 33.3 & 110649 & 87413 & 23236 & 26.6 \\
\hline $\begin{array}{c}\text { Trihozan } \\
\text { (seed } \\
\text { treatment) } \\
+ \text { Vitariz } \\
\text { (seed and } \\
\text { plant } \\
\text { treatment) }\end{array}$ & 5.3 & 49.9 & 158645 & 114467 & 44178 & 38.6 \\
\hline $\begin{array}{c}\text { Trihozan } \\
\text { (seed } \\
\text { treatment) } \\
+ \text { Vitariz } \\
\text { (seed and } \\
\text { plant } \\
\text { treatment) } \\
+ \\
\text { Bioinsectici } \\
\text { de (plant } \\
\text { treatment) } \\
\end{array}$ & 5.6 & 52.6 & 167267 & 120646 & 46621 & 38.6 \\
\hline
\end{tabular}

The level of profitability with the combined use of biological products against the background of the aftereffect of green manure increased by $11.7 \%$ compared to the control without biological products. Treatment of seeds with biological products did not have a significant effect on productivity and economic efficiency (Table 8).

\section{Conclusion}

Green manure predecessors had an effective effect and aftereffect on the formation of elements of the structure of the crop in both years of research. The largest increases in straw and seed yield were obtained when flax was placed after green manure predecessors and the complex use of biological products Trichozan, Vitariz, and Bioinsecticide. The straw yield when using biological products was, respectively, by years 104.0 $52.6 \mathrm{c} / \mathrm{ha}$, seeds: $15.5-5.6 \mathrm{c} / \mathrm{ha}$, the level of profitability increased by $41.9-11.7 \%$. The total yield of flax products decreased in 2020 compared to 2019 due to an increase in the weediness of crops and a decrease in plant density. The quality of flax straw improved by 0.5 sortonomer when the complex of biological products interacted with the action of green manure and by 0.25 sortonomer when using biological products for treating seeds and plants against the background of green manure aftereffect. The level of profitability of the cultivation of fiber flax with the use of biological products increased by $41.9 \%$ against the background of the action of green manure predecessors and by $11.7 \%$ against the background of their aftereffect.

\section{References}

1. A. S. Bashkov, T. Yu. Bortnik J. Agrarian Bulletin of the Urals, 1 (93), 19. (2012).

2. G.V. Efremova, E.Yu. Zotova J. Modern science: topical problems of theory and practice, 8, 20-24. 
(2020).

3. B.S. Dolgov, V. B. Kovalev Methodical instructions for carrying out field experiments with fiber flax. (VNIIL, Torzhok, 1978).

4. E.V. Korepanova Adaptive technology of cultivation of fiber flax for fiber and seeds in the Middle Urals. Abstract of the $\mathrm{PhD}$ dissertation (Ufa, Izhevsk State Agricultural Academy, 2014).

5. O.V. Melnikova Theory and practice of agriculture biologization. (St. Petersburg, Lan, 2019).

6. Yu.V. Chudinova Scientific basis for the rational use of biological resources of flax. Abstract of the $\mathrm{PhD}$ dissertation (Tomsk GU of control systems and radio electronics, Tomsk, 2011)

7. S. T. Esedullaev, I.G. Meltsaev J. Agrarian Bulletin of the Urals, 11 (190), 24, (2019).

8. S.V. Yakovleva, A.S. Vasiliev J. Vestnik Kras. $G A U$, 4, 16-23. (2020). 